\title{
EFFECTS OF DISORGANIZED URBANIZATION ON ENVIRONMENT
}

Urbanization has long been associated with human development and progress, but recent studies have shown that urban settings can also lead to significant inequalities and health problems. ${ }^{1}$ In the influence of disorganized urbanization on the environment, we focus on analyzing the Latin American region.

Indeed, urbanization developed rapidly in Latin America around the 20th century. Overall, approximately $70 \%$ of the Latin American population now lives in cities ${ }^{2}$. According to BBVA Research, urbanization in Latin America began earlier than in other regions and has managed to develop at a much faster pace. In addition, and keeping in mind the characteristics of Latin America, this increase in the levels of urbanization has greater merit, if one takes into account the low levels of income, capital, employment and productivity ${ }^{3}$. However, about $25 \%$ of the region's urban population - more than 160 million people - live in slums ${ }^{4}$. In addition, Mexico and Brazil have more than 12 cities with more than 1 billion inhabitants. ${ }^{3}$ The impact of this disaster is that millions of people have to live in the slums ${ }^{4}$. It also causes environmental pollution, depletion of resources, and many new diseases... (more than $77 \%$ of Latin Americans lack sanitation and only $28 \%$ of the region's wastewater collected from sewers is treated .... $)^{4}$

Humans contribute to disorganized urbanization. Because of uncompleted land reform and poor management by the government, many people migrated to the cities massively. ${ }^{1}$ Several Latin American governments have implemented policies to promote public housing programs, such as in Brazil, Chile, Argentina ${ }^{4} .$. However, the projects are limited to the periphery of the city and do not integrate with public transport and services which impact the distribution of land resources. At times, unplanned urban development (Inostroza, 2016) and adjacent vulnerable coastal environments, such as bays, estuaries, coral reefs and mangroves, can be degraded and fragmented (Barragán and de Andrés, 2016)...5

In recent years, Latin America has witnessed the fastest rate of urban growth in history. For example, the degree of urbanization in Brazil has increased significantly from $36 \%$ in 1950 , reaching an even balance between the rural and urban populations in the 1970s, up to $82 \%$, which is the urbanization level of this country. ${ }^{6}$ It makes people's lives harder to improve, and adversely affects the environment. Firstly, pollution is getting more and more serious. Motor vehicles, factories and other sources create so much air pollution that it may hang in the air like dirty fog. Untreated water releases substances into bodies of water that makes water unsafe for human use and disrupts aquatic ecosystems. Additionally, traffic is congested due to demand-supply imbalance in the transportation network. Traffic flow slows down when the number of vehicles traveling on the road are numerous. Public services are overloaded, creating great pressure on accommodation. As well as jobs for immigrants, social evils are likely to arise causing negative consequences in all aspects including: smoking, trafficking, transporting addictive substances, 
buying and selling sex, theft, robbery of murder, gambling in any form....Drug use, indiscriminate sex or sex work tells how many people have fallen, on the other hand, it is the fastest way to get HIV or AIDS affecting social order such as theft, prostitution, etc. There is a surplus of the labor force in urban areas and a shortage in rural areas. ${ }^{2}$ Moreover, urbanization causes production in the countryside to stagnate as labor moves to the city.Urban areas are under pressure of unemployment, overload for infrastructure, pollution of the living environment, unsecured social security, social evils such as underemployment will cause many problems such as backward poverty, illiteracy, evils like theft. ${ }^{2}$

There are a number of viable solutions to help tackle this problem. The United Nations recommends that this region continue to promote policies to support poor households to successfully enter the labor market, expand the labor market for women to diversify their income sources. households, and at the same time strengthen programs to support the poor in rural areas. These will be effective solutions to solve the problem of the gap between rich and poor in Latin America. The first solution is that all levels of government need to come up with visions and plans for their cities to reduce the disparity between living standards and living conditions in cities, avoiding spontaneous urbanization. To achieve this, Latin American countries have emphasized the role of sound financial policies in implementing social programs. Latin American countries lead the world in social programs through financial assistance and health services to the poor. This is the key to reducing poverty in 18 Latin American countries.. In additon, the Latin American government has taken steps to promote pro-poor urban infrastructure, especially in housing by taking the case of public housing programs such as those in Brazil, Chile ,and Argentina, along with similar programs in Peru and Uruguay. Moreover, the government has been more proactive in land acquisition, developing smarter zoning rules and entering into joint ventures. Housing and public services are built closer to the city center. Finally, in some cases, local governments will also need to encourage rental housing (including tax incentives) ${ }^{4}$

In summary, urbanization is now about $80 \%$ in Latin American countries. However, after strong growth, urbanization in Latin America shows signs of slowing down. ${ }^{7}$ Leaders have an important role in developing visions and implementing commitments to overcome difficulties and solve environmental and economic problems. The importance of urban planning, building codes, environmental policies and the emphasis on property management and preservation has facilitated the maintenance of an efficient urban system, with a high quality of amenities and vibrancy. To be sustainable, risks must be accepted when changes occur to community attitudes, technology, governance and urban management solutions. ${ }^{8}$ In particular, urbanization must also be more actively associated with digitization in the future. ${ }^{7}$ Consequently, some new trends appear, such as, in 2050, $90 \%$ of Latin America's population will live in urban areas. 


\section{Reference links:}

1. Kuddus, M. A., Tynan, E. \& McBryde, E. Urbanization: A problem for the rich and the poor? Public Health Rev. 41, 1-4 (2020).

2. Uncontrolled urban development |World Problems \& Global Issues | The Encyclopedia of World Problems. UIA: UNION OF INTERNATIONAL ASSOCIATIONS (2020).

3. Manuel Rado Quirós. Growth of urbanization slows in Latin America| BBVA. BBVA Group https://www.bbva.com/en/growth-urbanization-slows-latin-america/ (2018).

4. Robert Muggah. Latin America's cities are ready to take off. But their infrastructure is failing them | World Economic Forum. SecDev Group, Igarape Institute (2018).

5. de Andrés, M., Barragán, J. M. \& Scherer, M. Urban centres and coastal zone definition: Which area should we manage? Land use policy 71, 121-128 (2018).

6. Barros, J. X. Urban growth in Latin American cities: exploring urban dynamics through agentbased simulation. (Birkbeck, University of London, 2004).

7. Urbanization in Latin America. BBVA Group https://www.bbvaresearch.com/wpcontent/uploads/2017/07/Urbanization-in-Latin-America-BBVAResearch.pdf?fbclid=IwAR0SDgV0WiQ6IPx8_mCS0vklTFTG5-hF9yV8faubRvtgo6R6GnkEvLY_1I (2017).

8. PGS.TS.KTS. Nguyễn Tố Lăng. Những bài học kinh nghiệm của thế giới và Việt Nam trong quá trình đô thị hoá và phát triển bền vững. Cổng Thông Tin Điện Tử Bộ Xây Dựng https://moc.gov.vn/tl/tin-tuc/51410/nhung-bai-hoc-kinh-nghiem-cua-the-gioi-va-viet-nam-trongqua-trinh-do-thi-hoa-va-phat-trien-ben-vung.asp (2018). 